\title{
REPRODUCTIVE TRAITS SELECTION IN NELORE BEEF CATTLE
}

\author{
Seleção para características reprodutivas em \\ bovinos de corte da raça Nelore
}

\author{
Heverton Luis Moreira ${ }^{1}$, Marcos Eli Buzanskas ${ }^{2}$, Danisio Prado Munari², \\ Érika Breda Canova ${ }^{3}$, Raysildo Barbosa Lôbo ${ }^{4}$, Claudia Cristina Paro de Paz ${ }^{3}$
}

\begin{abstract}
Genetic breeding programs of beef cattle in Brazil are including new features, mainly related to reproductive efficiency. Thus, it is necessary to study the effectiveness of selection and quantify genetic gain for these traits in herds. This study estimated genetic and phenotypic parameters and genetic trends for reproductive traits used in breeding programs for Nelore beef cattle. The traits studied were the scrotal circumference (SC) at 365 and 450 days of age (SC365 and SC450), age at first calving (AFC) and gestation length, as a cow trait (GLcow) and a calf trait (GLcalf). The (co)variance components were obtained with the Restricted Maximum Likelihood Methodology in a single and double-trait analysis of the animal model. For scrotal circumference (SC365 and SC450), positive and favorable genetic gains were observed. For AFC, GLcow and GLcalf, the trends were favorable for selection, but without significant genetic gain. Selection for large SC may reduce AFC and improve female reproductive efficiency. The selection for reproductive traits (SC365, SC450, AFC and GL) may improve reproductive and productive efficiency of Nelore cattle, if used as a selection criterion.
\end{abstract}

Index terms: Reproductive efficiency; genetic evaluation; precocity.

\begin{abstract}
RESUMO
Os programas de avaliação genética de bovinos de corte, no Brasil, estão incluindo novas características, principalmente as ligadas à eficiência reprodutiva. Dessa forma, faz-se necessário estudar a efetividade da seleção e quantificar ganho genético para estas características nos rebanhos selecionados. Objetivou-se, neste estudo, estimar parâmetros genéticos e fenotípicos e tendências genéticas para características reprodutivas utilizadas em programas de avaliação genética de bovinos de corte da raça Nelore. As características estudadas foram o perímetro escrotal aos 365 e 450 dias de idade (PE365 e PE450), idade ao primeiro parto (IPP), período de gestação considerada como característica da vaca (PGvaca) e do bezerro (PGbez). Os componentes de (co) variância foram obtidos pelo Método de Máxima Verossimilhança Restrita em análises uni e bi-características, sob o modelo animal. Para o perímetro escrotal (PE365 e PE450), foi observado ganho genético positivo e favorável. Para IPP, PGvaca e PGbez as tendências foram no sentido favorável da seleção, porém sem ganho genético significativo. A seleção para maior perímetro escrotal pode reduzir a IPP e melhorar a eficiência reprodutiva das fêmeas. A seleção para características reprodutivas (PE365, PE450, IPP e PG) pode melhorar a eficiência reprodutiva e produtiva do rebanho, se forem usadas como critérios de seleção para bovinos da raça Nelore.
\end{abstract}

Termos para indexação: Eficiência reprodutiva; avaliação genética; precocidade.

\section{INTRODUCTION}

New market concepts aim toprovide agricultural and livestock products in sustainable production systems. Animal genetic breeding is one of the multidisciplinary tools for this new beef cattle system to meet basic requirements of the sustainable production process. Genetic breeding allowstoreduce production cycle, maximizing productive and reproductive potential of the herd, that is, animals with precocious sexual development, growth and carcass finishing. This can increase improve quality and increase production of Brazilian meat products.

Traits related to reproduction have a great impact on profitability in animal production systems. Thus, selection criteria connected to with sexual precocity and reproductive efficiency have been used widely in genetic breeding programs in Brazil (Lôbo et al., 2010).

According to Silva et al. (2011), scrotal circumference (SC) is easily measured and is directly associated with sexual precocity and sperm quantity and quality, which may lead to favorable reproductive trends

${ }^{1}$ Agência Paulista de Tecnologia dos Agronegócios/APTA - Instituto de Zootecnia - Highway: Carlos Tonanni - km 94 - Setor Industrial Água Vermelha 14174-000 - Sertãozinho - SP - Brazil - hlmoreira@usp.br

2Universidade Estadual Paulista Júlio de Mesquita Filho/UNESP-Faculdade de Ciências Agrárias e Veterinárias de Jaboticabal - NovaAparecida-Jaboticabal -SP-Brasil

${ }^{3}$ Agência Paulista de Tecnologia dos Agronegócios/APTA - Instituto de Zootecnia - Sertãozinho - SP - Brasil

${ }^{4}$ Universidade de São Paulo/USP - Faculdade de Medicina de Ribeirão Preto - Departamento de Genética - Monte Alegre - Ribeirão Preto - SP - Brasil

Received in november 13, 2014 and approved in february 24, 2015

Ciênc. Agrotec., Lavras, v. 39, n. 4, p. 355-362, jul./ago., 2015 
in young bulls (Lôbo 1992). This trait is considered of moderate to high heritability magnitude ( 0.24 to 0.67 ), indicating that early selection allows higher potential for genetic gain through direct selection (Gressler et al., 2000; Pereira; Eler; Ferraz, 2000; Mercadante; Lôbo; Oliveira, 2000). SC has a favorable genetic association with other reproductive traits (Boligon et al. 2010), also in females (Van-Melis et al., 2010), as well as an association with scrotal circumference and productive traits (Yokoo et al., 2007).

Age at first calving (AFC) is used in breeding programs of Nelore cattle as an indicator trait for female sexual precocity. It directly influences production efficiency and provides economic benefits by reducing production cycles (Gunski et al., 2001). Heritability coefficients found in many studies range from low to moderate magnitude ( 0.03 to 0.39 ), showings that heritability has genetic variability, however, the influence of environmental factors does not allow its full potential to be expressed (Gressler et al., 2005). The importance of heritability in breeding programs is attributed to its favorable genetic and phenotypic associations with growth (Boligon et al., 2010) and reproductive traits (Grossi et al., 2009).

Although gestation length (GL) itself is nota measurement of fertility, it is closely related to the reproductive period. Cows have a gestation period between 284.73 and 295.3 days, with little variation of average values (Azevêdo et al., 2006; Boligon; Rorato; Albuquerque, 2007). Chud et al. (2014) found direct heritability coefficient of 0.38 , whereas Pereira, Eler and Ferraz (2000) found 0.13 . This variation in heritability estimations indicates that genetic and non-genetic factors can influence GL, such as birth season, birth year, gender and weight, which justifies its inclusion in breeding programs (Pereira; Eler; Ferraz, 2000; Mucari et al., 2007).

Measuring of genetic gains in traits responsible for sexual precocity, growth and carcass finishing is of great importance, because it allows to evaluate changes in the selection process over the years in a specific herd (Zollinger and Nielsen 1984). Such measurements guide breeders in future actions for genetic breeding of the herd (EuclidesFilho et al., 2000; Malhado et al., 2008).

This study estimated genetic and phenotypic parameters and genetic trends for SC, AFC, GL (cow and a calf traits) in Nelore beef cattle of a genetic breeding program (Nelore Brazil Program), aiming to quantify the potential for genetic gains in these reproductive traits.

\section{MATERIAL AND METHODS}

We used data from animals born between 1998 and 2008, from 22 herds of Nelore Genetic Breeding Program (Nelore Brazil), coordinated by the National Breeders and Researchers Association (ANCP). All animals in the program undergo zootechnical monitoring of reproductive and productive traitsand are kept in an extensive or semiextensive feeding regimen. The reproductive management consisted of artificial insemination of females during the mating period, when they were kept in corrals with clean-up bulls.

In males, $\mathrm{SC}$ was measured in centimeters $(\mathrm{cm})$, corrected to 365 days of age (SC365) and 450 days of age (SC450). In females, AFC was measured in months, obtained from the difference between the birth date and date of first calving; GL was measured in days, obtained from the difference between insemination date and calving date, which was obtained for cow trait (GLcow) and calf trait (GLcalf).

Contemporary groups (CG) were defined based on the analysis performed in the least square method, using the GLM procedure of the SAS software (SAS, 2002-2003), to define the fixed effects in the mixed models. Farm data (Nfa), year of birth (YoB), season of birth (SoB), defined as $1=$ dry (April to September) and $2=$ rainy (October to March), management batch (Batch 120, 365 and 450 days), Sex (Sx) and dam age at calving (Dac) significantly affected $(\mathrm{P}<0.005)$ the studied traits. $\mathrm{CG}$ were defined as SC365: Nfa + YoB + SoB + Batch120+Batch365; SC450: $\mathrm{Nfa}+\mathrm{YoB}+\mathrm{SoB}+$ Batch $120+$ Batch $365+$ Batch450; AFC: $\mathrm{YoB}+\mathrm{SoB}+$ Batch $120+$ Batch $365+$ Batch450; GLcow: $\mathrm{Sx}+\mathrm{Nfa}+\mathrm{Dac}$; GLcalf: $\mathrm{Sx}+\mathrm{Nfa}+\mathrm{YoB}+\mathrm{SoB}$ + Dac.

Normality of residuals was carried out inthe Cramer-von Mises test, however, normality was not observed for the studied data. Standardized residuals were used to evaluate discrepant data. Observations where residuals were higher than 3.5 standard deviations and lower than -3.5 standard deviations were excluded.

After ensuring data file consistency, descriptive statistical estimates were produced for the following traits: SC365 (cm), SC450 (cm), AFC (months), GLcow (days) and GLcalf (days) (Table 1).

The analyses of variance component estimation were performed with REML using the animal model. The fixed effect (CG), random effect (direct additive) and residual error effect were considered for all traits. The covariable of dam age at calving had significant 
linear and quadratic $(\mathrm{P}<0.05)$ values for $\mathrm{SC} 365, \mathrm{SC} 450$, GLcow and GLcalf. For SC365, SC450 and AFC, the model included only random and direct additive genetic effects. For GLcow, the model included direct additive genetic effects and permanent environment. For GLcalf, the model included random direct additive and maternal genetic effects.

The estimates for (co) variance components, genetic parameters and breeding values for the traits studied were obtained in REML, in a multi-trait animal model, using WOMBAT computer software (Meyer, 2007).

The annual genetic gains of SC365, SC450, AFC, GLcow and GLcalf were estimated in linear regression of breeding value $(\mathrm{BV})$ based on year of birth. The significance of Geometric Growth Rate - GGR was evaluated using the " $\mathrm{t}$ " test. The GGR values indicate the mean linear change in the breeding value (\%) for each variable.

\section{RESULTS AND DISCUSSION}

The estimates of variance components and direct and maternal heritability for the traits studied (SC365, SC450, AFC, GLcow and GLcalf) are shown in Table 2.
Heritability estimations obtained for SC measured at 365 and 450 days of age were 0.41 and 0.44 , respectively, similar to estimations described in the literature that, ranged from 0.42 to 0.53 (Pereira; Eler; Ferraz, 2002; Garnero et al., 2002; Dias; El Faro; Albuquerque, 2003; Gianlorenço et al., 2003; Yokoo et al., 2007). These values were very similar, indicating that the used of the same selection intensity at both agesfavors the response for the selection of SC365 because genetic gains of this trait are associated to economic returns, with the choice of sexually precocious bulls fit for the breeding season.

Heritability for AFC was 0.20 , showing that this value can be related to the analysis method that considered only females with their first birth on the farm or other factors such as nutrition and mating criteria used for steers exposure as cited by Pereira, Eler and Ferraz (2002) and Dias, El Faro and Albuquerque (2004). Therefore, AFC genetic variability can be obtained from direct selection, however, the methods cited above should be improved in order to explore the trait variability, which could bring direct economic efficiency, profitability and competitiveness of Brazilian cattle (Boligon; Rorato; Albuquerque, 2008).

Table 1: Number of animals, number of contemporary groups (CG), mean, standard deviation (SD), minimum (Min) and maximum (Max) for the analyzed traits.

\begin{tabular}{ccccccc}
\hline Trait* & Animals & CG & Mean & SD & Min & Max \\
\hline SC365 $(\mathrm{cm})$ & 18747 & 837 & 20.43 & 2.25 & 12.30 & 30.00 \\
SC450 $(\mathrm{cm})$ & 18430 & 924 & 23.64 & 3.06 & 12.80 & 35.90 \\
AFC (months) & 13329 & 875 & 35.16 & 4.98 & 21.00 & 49.00 \\
GLcow (days) & 22382 & 2335 & 296.49 & 5.85 & 277.00 & 314.00 \\
GLcalf (days) & 12283 & 2427 & 296.66 & 5.75 & 277.00 & 314.00 \\
\hline
\end{tabular}

* Scrotal circumference at 365 (SC365) and 450 (SC450) days of age, age at first calving (AFC), gestation length as a cow trait (GLcow) and gestation length as a calf trait (GLcalf).

Table 2: Additive $\left(\sigma_{\mathrm{a}}^{2}\right)$, residual $\left(\sigma_{\mathrm{e}}^{2}\right)$ and phenotypic $\left(\sigma_{\mathrm{p}}^{2}\right)$ genetic variance components, maternal additive variance $\left(\sigma_{\mathrm{am}}\right)$, maternal variance $\left(\sigma_{\mathrm{m}}^{2}\right)$, permanent environment $\left(\sigma_{\mathrm{ep}}^{2}\right)$, direct heritability with standard error $\left(\mathrm{h}_{\mathrm{d}+\mathrm{SE}}^{2}\right)$ and maternal heritability with standard error $\left(\mathrm{h}_{\mathrm{m}+\mathrm{SE}}{ }^{2}\right.$, in a single-trait analysis.

\begin{tabular}{crrrrrrc}
\hline Trait* & \multicolumn{1}{c}{$\sigma_{a}^{2}$} & \multicolumn{1}{c}{$\sigma_{\mathrm{e}}^{2}$} & $\sigma_{\mathrm{am}}$ & $\sigma_{\mathrm{m}}^{2}$ & $\sigma_{\mathrm{ep}}^{2}$ & $\mathrm{~h}_{\mathrm{d}+\mathrm{SE}}$ & $\mathrm{h}^{2}{ }_{\mathrm{m}+\mathrm{SE}}$ \\
\hline $\mathrm{SC} 365$ & 120.37 & 171.62 & ---- & ---- & ---- & $0.41 \pm 0.02$ & ---- \\
$\mathrm{SC} 450$ & 226.60 & 286.14 & ---- & ---- & ---- & $0.44 \pm 0.02$ & ---- \\
AFC & 3.12 & 12.50 & ---- & ---- & ---- & $0.20 \pm 0.02$ & ---- \\
GLcow & 6.14 & 23.21 & ---- & ---- & 1.40 & $0.20 \pm 0.01$ & ---- \\
GLcalf & 14.01 & 12.62 & -0.62 & 2.67 & ---- & $0.49 \pm 0.05$ & $0.09 \pm 0.02$ \\
\hline
\end{tabular}

* Scrotal circumference at 365 (SC365) and 450 (SC450) days of age, age at first calving (AFC), gestation length as a cow trait (GLcow) and gestation length as a calf trait (GLcalf). 
The GL evaluated in this study aimed to show if it should be explored in the analysis as genetically influence of the cow (GLcow) or calf (GLcalf), where the coefficient of heritability was larger for GLcalf $(0.49 \pm 0.05)$ compared to GLcow $(0.20 \pm 0.01)$, which corroborates the study of Mucari et al. (2011) in Canchim. Thus, the GL analyzed as a calf trait could result in greater genetic gain by direct selection, reducing the period, increasingthe success of pregnant females in the breeding season (Pereira; Eler; Ferraz, 2002), thus, justifying its inclusion into genetic breeding programs.

The genetic and phenotypic correlations between the traits studied are presented in Table 3. The genetic correlation between SC365 and SC450 (0.96) indicates that most genes responsible for SC at 365 days of age also influence at 450 days. This result is in agreement with Gressler et al. (2000) who found a genetic correlation between SC365 and SC450 of 0.99 and 0.72 phenotypic. Thus, in the selection of bulls with larger SC365, the correlated response at SC450 is the same.

Genetic correlation estimates between SC365 and SC450 were then associated to AFC (Table 3), and the results obtained were -0.40 at $\mathrm{SC} 365$ from $\mathrm{AFC}$ and -0.37 at SC450 from AFC, indicating that bull selection based on larger SC at both ages reduces AFC of their female offspring. The literature reported negative results of associations SC and AFC in Nelore ranging from -0.22 to -1.00 (Gressleret al., 2000; Pereira; Eler; Ferraz, 2000; Pereira; Eler; Ferraz, 2002; DIAS et al., 2003). This shows that the indirect gains of selection to promote $\mathrm{SC}$ at first calving, which is economically viable for beef cattle production systems, because measuring $\mathrm{SC}$ is somewhat easily for a low cost.

Genetic correlations between SC365/SC450 days and GLcalf were favorable and negative -0.21 and -0.19 respectively, suggesting that selection for SC could reduce GLcalf, but not in GLcow, where the results were virtually null. AFC also showed favorable genetic associations with GLcalf (0.28) and GLcow (0.19), where gains from selection for reduced AFC also promoted positive impacts on GL.Therefore, the GL as a calf trait had the highest favorable genetic associations with the PE and IPP, that is, selection of bulls with larger SC and females with early AFCcould promote indirect reduction of gestational period of the mother, bringing all benefits to improve production systems.

Estimates of genetic trends allow to evaluate how the selection process changes over the years, considering the mean breeding value. Thus, these estimates test the efficacy of the proposed selection indexes for the traits selected. In this study, the selection applied to the males to obtain animals with greater SC at 365 (Figure 1A) and 450 (Figure 1B) days of age, provided genetic gains of $0.025 \mathrm{~cm} /$ year and $0.034 \mathrm{~cm} /$ year $(\mathrm{P}<0.0001)$, respectively.

This trend is very clear regarding genetic gain for SC. An increase of $0.12 \%$ (SC365) and $0.14 \%$ (SC450) per year was observed, in relation to the expected mean for Nelore cattle during the period evaluated. This result was lower than the findings of Cyrillo et al., (2001), who compared a herd under constant selection with a control herd. The animals in the selection herd had an increase of $0.31 \mathrm{~cm} /$ year, whereas the animals in the control herd showed a decrease of $0.21 \mathrm{~cm} /$ year for the trait. Therefore, direct selection for bulls with larger SC promoted positive changes, in the studied period, to breeding values of Nelore, which is desirable for program that uses selections as a criterion, considering their genetic associations favorable with other economically important traits for production systems mentioned in this study.

Table 3: Estimates of genetic correlations (above diagonal) and phenotypic correlations (below diagonal) and respective standard errors in the traits studied.

\begin{tabular}{cccccc}
\hline Trait* & SC365 & SC450 & AFC & GLcow & GLcalf \\
\hline SC365 $(\mathrm{cm})$ & --- & $0.96 \pm 0.01$ & $-0.40 \pm 0.01$ & $0.02 \pm 0.01$ & $-0.21 \pm 0.01$ \\
SC450 $(\mathrm{cm})$ & $0.85 \pm 0.01$ & ---- & $-0.37 \pm 0.01$ & $-0.01 \pm 0.01$ & $-0.19 \pm 0.01$ \\
AFC (months) & $0.16 \pm 0.01$ & $-0.04 \pm 0.01$ & ---- & $0.19 \pm 0.01$ & $0.28 \pm 0.01$ \\
GLcow (days) & $0.02 \pm 0.01$ & $0.01 \pm 0.01$ & $0.04 \pm 0.01$ & ---- & ---- \\
GLcalf (days) & $0.05 \pm 0.01$ & $0.01 \pm 0.01$ & $0.05 \pm 0.01$ & ---- & ---- \\
\hline
\end{tabular}

* Scrotal circumference at 365 (SC365) and 450 (SC450) days of age, age at first calving (AFC), gestation length as a cow trait (GLcow) and gestation length as a calf trait (GLcalf).

Ciênc. Agrotec., Lavras, v. 39, n. 4, p. 355-362, jul./ago., 2015 
Genetic gain for AFC (Figure 2) was -0.01 months/year $(\mathrm{P}<0.0001)$, and although practically null, it still represents a yearly decrease of $0.02 \%$, showing indirect gains for the trait through selection. The result of low yearly genetic gain for AFC may have reflected on management methods used on farms and genetic evaluation models, and these reductions do not express the potential that breeders expect for females.

The genetic trend for AFC in female Gir cattle showed an increase of 0.008 months/year (Balieiroet al., 1999). Júnior et al., (2010), also studied Gir cattle and found favorable genetic trends, with a yearly gain of -0.018 months. Laureano et al., (2011) studied beef cattle and found a reduction of 1.5 days/ year for female Nelore cattle that were challenged precociously. Thus, studies show that estimates for genetic trends have been favorable regarding the genetic potential of sexual precocity, although without significant genetic progress for age at first calving.

Genetic trend estimates for GL considered cow and calf as traits are presented in Figure 3. The genetic change in GL, considering cow responsible for the period, was -0.02 days/year, equal to a mean genetic gain of $-0.006 \%$ per year. When the gestation period considered a calf trait, the genetic trend was -0.008 days/year, equal to $-0.002 \%$ per year.
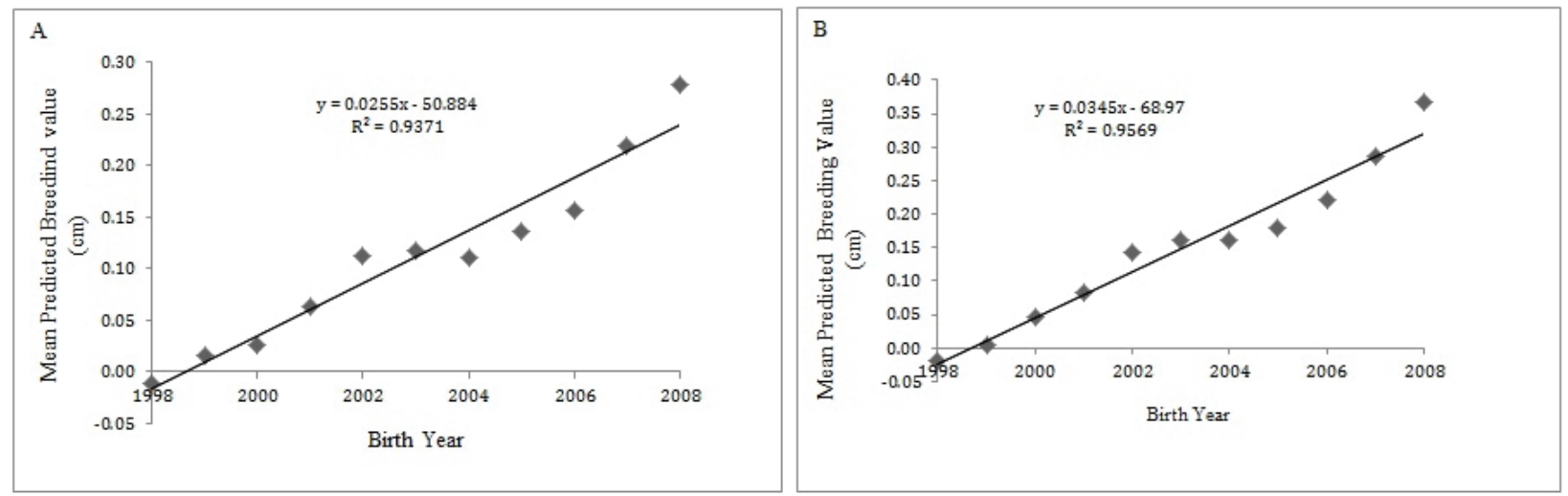

Figure 1: Mean predicted breeding value variation for: (A) scrotal circumference at 365 days of age (SC365), and (B) scrotal circumference at 450 days of age (SC450). The regression coefficients were significantly different $(\mathrm{P}<0.001)$ from zero using the $\mathrm{t}$ test.

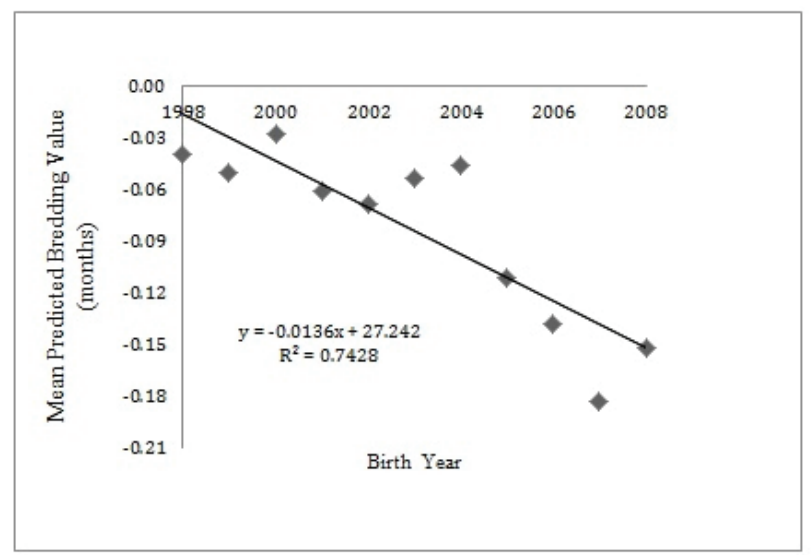

Figure 2: Mean predicted breeding value variation for age at first calving (AFC). The regression coefficients were significantly different $(\mathrm{P}<0.001)$ from zero using the $\mathrm{t}$ test. 

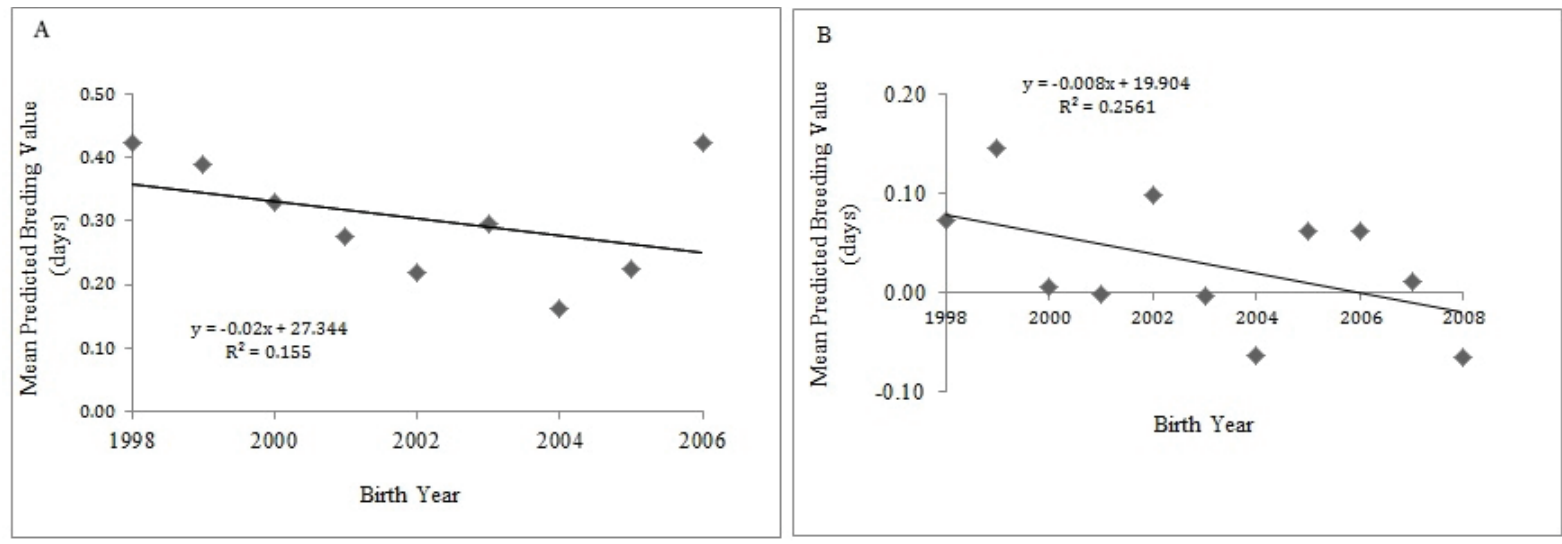

Figure 3: Mean predicted breeding value variation for: (A) gestation length considering a cow trait (GLcow) and (B) a calf trait (GLcalf). The regression coefficients were significantly different $(\mathrm{P}<0.001)$ from zero using the $t$ test.

These practically null gains were expected for AFC and GL (cow and calf) traits, since they have become part of the genetic selection index in the Nelore Brazil Program since 2008. Over the period analyzed in the current study, these traits were not part of direct or indirect selection process, which explains the non-significant genetic gains for GL and AFC. From 2008, these traits were included in the selection index, and therefore the genetic gains for GL $\mathrm{AFC}$ in the coming years are different. This suggests that selection for SC (365 and 450), AFC and GL are important in Nelore cattle genetic breeding programs, as these traits may influence economic and socio-environmental issues of the Brazilian beef cattle production and maximize the objectives of selection for sexual precocity in animal breeding systems.

\section{CONCLUSIONS}

Direct selection for SC365 and SC450 traits is expected to provide greater genetic gains than the reproductive traits evaluated in females (AFC and GLcow). The resultant gains are favorable through the positive genetic trend rates.

For AFC, greatly influenced by the environment, environmental improvements related to reproductive management will allow females to be better evaluated and consequently selected, possibly increasing their reproductive rates.

Direct selection of GL as a calf trait may bring greater genetic gain than when selected as a cow trait.

The inclusion AFC in the selection of objectives associated with information at SC365 as a selection criterion can promote greater economic response, due to its economic impact on beef cattle production systems.

\section{REFERENCES}

AZEVÊDO, D.M.M.R. et al. Desempenho reprodutivo de vacas Nelore no norte e nordeste do Brasil. Revista Brasileira de Zootecnia. 35(3):988-996, 2006.

BALIEIRO, E.S. et al. Estimativas de parâmetros genéticos e de tendência fenotípica, genética e de ambiente de algumas características reprodutivas na raça Gir. Arquivos Brasileiros de MedicinaVeterinária e Zootecnia. 51(4):371-376, 1999.

BOLIGON, A.A.; RORATO, P.R.N.; ALBUQUERQUE, L.G. Correlações genéticas entre medidas de perímetro escrotal e características produtivas e reprodutivas de fêmeas da raça Nelore. Revista Brasileira de Zootecnia. 36(3):565-571, 2007.

BOLIGON, A.A.; ALBUQUERQUE, L.G.; RORATO, P.R.N. Associações genéticas entre pesos e características reprodutivas em rebanhos da raça Nelore. Revista Brasileira de Zootecnia. 37(4):596601, 2008.

BOLIGON, A.A. et al. Study of relations among age at first calving, average weigth gains and weights from weaning to maturity in Nellore cattle. Revista Brasileira de Zootecnia. 39(4):746-751, 2010.

CHUD, T.C.S. et al. Genetic analysis for gestation length, birth weight, weaning weight, and accumulated productivity in Nellore beef cattle. Livestock Science. 170:16-21, 2014. 
CYRILLO, J.N.S.G. et al. Estimativas de tendências e parâmetros genéticos de peso padronizado aos 378 dias de idade, medidas corporais e perímetro escrotal em machos Nelore de Sertãozinho, SP. Revista Brasileira de Zootecnia. 30(1):56-65, 2001.

DIAS, L.T.; EL FARO, L.; ALBUQUERQUE, L.G. Estimativas de herdabilidade para perímetro escrotal de animais da raça Nelore. Revista Brasileira de Zootecnia. 32(6):1878-1882, 2003.

DIAS, L.T.; EL FARO, L.; ALBUQUERQUE, L.G. Efeito da idade de exposição de novilhas à reprodução sobre estimativas de herdabilidade da idade ao primeiro parto em bovinos Nelore. Arquivos Brasileiros de Medicina Veterinária e Zootecnia. 56(3):370-373, 2004.

EUCLIDES FILHO, K. et al. Tendência Genética na raça, Brasília Gir. Pesquisa Agropecuária Brasileira. 34(4):787-791, 2000.

GARNERO, A.D.V. et al. Influência da incorporação de dados de progênies na classificação de touros da raça Nelore. Revista Brasileira de Zootecnia. 31(2):918923, 2002.

GIANLORENÇO, V.K. et al. Herdabilidades e correlações genéticas de características de machos e fêmeas, em um rebanho bovino da raça Canchim. Revista Brasileira de Zootecnia. 32(6):1587-1593, 2003.

GRESSLER, S.L. et al. Estudos das associações genéticas entre perímetro escrotal e características reprodutivas de fêmeas Nelore. Revista Brasileira de Zootecnia. 29(2):427-437, 2000.

GRESSLER, M.G.M. et al. Aspectos genéticos do peso à desmama e de algumas características reprodutivas de fêmeas Nelore. Arquivos Brasileiros de Medicina Veterinária e Zootecnia. 57(4):533-538, 2005.

GROSSI, D.A. et al. Genetic associations between age at first calving and heifer body weight and scrotal circumference in Nellore cattle. Journal of Animal Breeding Genetics. 126(5):387-393, 2009.

GUNSKI, R.J. et al. Idade ao Primeiro parto, período de gestação e peso ao nascimento na raça Nelore. Ciência Agronômica. 32(1/2):46-52, 2001.
JÚNIOR, M.L.S. et al. Parâmetros genéticos de características reprodutivas de touros e vacas Gir leiteiro. Revista Brasileira de Zootecnia. 39(8):17171722, 2010.

LAUREANO, M.M.M. et al. Estimativas de herdabilidade e tendências genéticas para características de crescimento e reprodutivas em bovinos da raça nelore. Arquivos Brasileiros de Medicina Veterinária e Zootecnia. 63(1):143-152, 2011.

LÔBO, R.B. Programa de melhoramento genético da raça nelore. USP. Ribeirão Preto, 1992. 58p.

LÔBO, R.B. et al. Avaliação genética das raças Nelore, Guzerá, Brahman e Tabapuã. Sumário. Ribeirão Preto: ANCP, 2010. 172p.

MALHADO, A.H.M. et al. Progresso genético e estrutura populacional do rebanho Nelore no Estado da Bahia. Pesquisa Agropecuária Brasileira, Brasília. 43(9):1163-1169, 2008.

MERCADANTE, M.E.Z.; LÔBO, R.B.; OLIVEIRA, H.N. Estimativas de $(\mathrm{Co})$ variâncias entre características de reprodução e de crescimento em fêmeas de um rebanho Nelore. Revista Brasileira de Zootecnia. 29(4):997-1004, 2000.

MEYER, K. Wombat - a tool for mixed model analyses in quantitative genetics by restricted maximum likelihood (REML). Journal of Zhejiang University

Science B. 8(11):815-821, 2007.

MUCARI, T.B. et al. Genetic analyses of days to calving and their relationship with other traits in Canchim catlle herd. Genetics and Molecular Biology. 30(4):1070-1076, 2007.

MUCARI, T.B. et al. Análise genética do período de gestação em animais de um rebanho Canchim: estimação de parâmetros genéticos e escolha entre modelos animais alternativos. Revista Brasileira de Zootecnia. 40(6):1211-1216, 2011.

PEREIRA, E.; ELER, J.P.; FERRAZ, J.B.S. Correlação genética entre perímetro escrotal e algumas características reprodutivas na raça Nelore. Revista Brasileira de Zootecnia. 29(6):1676-1683, 2000. 
PEREIRA, E.; ELER, J.P.; FERRAZ, J.B.S. Análise genética de características reprodutivas na raça Nelore. Pesquisa Agropecuária Brasileira. 37(5):703-708, 2002.

SAS, System for Windows ${ }^{\circledR}$. Version 9.1, SAS Inst Cary, NC, USA, 2002/2003.

SILVA, M.R. et al. Testicular traits as selection criteria for young Nellore bulls. Journal of Animal Science. 89(7):2061-2067, 2011.

VAN MELIS, M.H. et al. Additive genetic relationships between scrotal circumference, heifer pregnancy, and stayability in Nellore cattle. Journal of Animal Science. 88(12):3809-3813, 2010.

YOKOO, M.J.I. et al. Estimativas de parâmetros genéticos para altura do posterior, peso e circunferência escrotal em bovinos da raça Nelore. Revista Brasileira de Zootecnia. 36(6):1761-1768, 2007.

ZOLLINGER, W.A; NIELSEN, M.K. An evaluation of bias in estimated breeding values for weaning weight in Angus beef cattle field records. I. Estimates of within herd genetic trend. Journal of Animal Science. 58(3):545-549, 1984. 